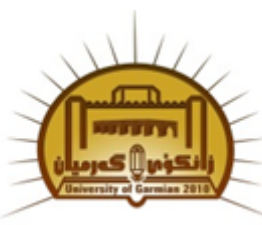

Available online at http://jgu.garmian.edu.krd

Journal of Uni versity of Garmian

https://doi.org/10.24271/garmian.1964027

\title{
Speech and Social Class in Emily Brontë's Wuthering Heights
}

\author{
Dlnya Abdalla Mohammed Ali
}

Department of English, School of Basic Education, University of Sulaimani

\section{Article Info}

Received: November, 2019

Revised: December, 2019

Accepted:December, 2019

\section{Keywords}

Emily Brontë, Wuthering Heights, Speech and Social status.

\section{Corresponding Author}

dilny a.mohammad@univsul.edu.iq

\begin{abstract}
Language is a human trait associated with a particular community or ethnicity; there are a range of languages that represent their existence. On the other hand, the diversity of language shows aspects of their communication. Language also reflects in social construction when humans communicate to each other. In other words, language is used in social class, social status, and educational background that are called social dialect; a variety of languages that reflect social variation in language use, according to certain factors related to the social group of the speaker such as education, occupation, income level, etc.

In this research, the characters' speech in Emily Brontë's Wuthering Heights (1847) is examined, in particular by dealing with spelling, grammar and lexis to explain what role speech plays in the character construction. The findings of this work indicate that this author of the Victorian literature used speech to both individualize characters and to bind them to a certain groups, which can mostly be defined by social status; a unique type of speech is provided to each main personality to denote his or her social status. A list of references is shared at the end.
\end{abstract}

\section{Introduction}

Emily Brontë's Wuthering Heights is one of the foremost criticized books in the English language. The pivotal structure of the novel and Emily Brontë's careful dealing with language has been debated intensely by contemporary critics. It is through the language that the fictional world of the novel is revealed to the reader.

The presentation of variations in numerous written works has shown in a great way that the linguistic behaviors experience significant influence from the hierarchies of social classes. For many studies, it is nearly impossible to disregard the connections that exist between social class and the use of language through the choice dialect for different types of characters (Yule 254). It is exceptionally striking that social class as an element of human relationships incorporates a compelling impact on the language attitudes of most groups even in written materials or narratives, as it would somehow have in real life. Social distance is the genesis of social dialect. With a close analysis of most literal narratives, it is almost impossible to miss the place and demonstration of class in the sociolinguistic relations therein. Class as an element of social structure within the context of human relationships produces a noticeable pattern in pronunciation when correlating it to language use. 
Social class indeed influences the grammatical and phonological usage of a language. Therefore; it is fairly acceptable to claim that the impact of choice on the use of a language by an individual stems from the hierarchy of the social structure from which that individual traces his or her background, as dialect works as a means of placing characters; not only in a particular area but also in the social hierarchy (Linn 237).

Several factors find use in the definitions granted to hierarchical social structures. These factors include the level of education, the type of occupation, the amount of income, and the type of accommodation that individuals can obtain. It is almost noticeable that those who have access to the highest level possible of the factors mentioned above can show a maximum care and attention in using their language. On the other hand, those who have access to the lowest level of the above factors show a lack of attention to their language use and pronunciation thereof. In fact, in the same way, that human social relations show class division through the hierarchies of social class, it is the same way that those social relationships exhibit stratification in language use (Chapman 39).

Those in the upper strata pay too much attention to the choice of their language use because the fact that most of the individuals in such rank may not want to become victims of scorn from their peers for wrong use of language or poor pronunciation. Therefore, those in the upper levels face the pressure to adopt a language variant that indicates a more standard use of the language in their communication.

Because of these differences in language use, and in most cases it could be the same language only appearing as different forms, it is possible to find the association of one variant with those in the highest social class while another variant being associated with those in the lowest level of the hierarchies of social structures. For instance, in the use of the English language, those who use Standard English both in communication and in pronunciation appear to fall within the classification of those from the highest social hierarchy. On the other hand, those who use Pidgin English, which is distinct, heavily influenced, by vernacular will tend to fall within the classification of those from the lowest social hierarchy. It is, therefore, common to witness members of the high social class exhibiting a careful orchestrated use of language compared to their counterparts from the low social class. In some cases, this monitoring of language use may be with the conscious knowledge or the unconscious awareness of the individual who is mindful of his or her language use (Mugglestone 61).

Authors and developers of narratives and associated written materials have taken advantage of this relationship between language and class has thus not failed to incorporate this relationship in their literature works. The evidence of the use of dialect is prominent in most of the Victorian literature works. In actual sense, the inclusion of the real world use of dialect in language influenced the popularity of the works of the Victorian fiction. Novels which include strong dialect were accepted and even appreciated in the nineteenth century because they reflect Victorian way of life and create a regional life experience (Chapman 56).

Delineation of mannerism associated with social class by the use of dialect is not exceptional in Emily Brontë's Wuthering Heights. Emily Brontë grants her characters particular dialects as a way of exposing the social strata that she identifies them within her narrative. The purpose of this study, therefore, is to outline the relationship exhibited between class and dialect in Emily Brontë's Wuthering Heights.

\section{Speech and Social Class in Emily Brontë's Wuthe ring Heights}

Not many novelists desired to render dialect speech as consistent and precise as Emily Brontë attempted to in her novel (Chapman 53). Joseph is the old servant at Wuthering Heights, who with much purity displays the Yorkshire dialect; a dialect, in contrast to the Yorkshire accent, is considered to be a foreign language because it represents a distinct pattern of grammar, spelling, vocabulary, pronunciation and intonation. It is an ancient form of speech that represents the language of Angles, Saxons and Vikings - the long-dropped links of Standard English (West Winds Yorkshire Tearooms).

Emily Brontë chooses non-standard spelling to elucidate Joseph's lack of education. Some words are merely misspelled (Chapman 21). Joseph leaves out a great number of mediate and final consonants, e.g. in ta'en (k), fro' (m), o' (f), cand'e-light (l), cham'er (b) , tum'le (b) , o'er (v), mista'en (k), or even $\operatorname{taen} / \operatorname{taan}(\mathrm{k})$ as in "This is t' way on't:-up at sun- 
down: dice, brandy, cloised shutters, und can'le-light till next day at noon: then, t'fooil gangs banning und raving to his cham'er" and "weel done, Miss Cathy! Howsiver, t' maister sall just tum'le o'er them brooken pots; un' then we's hear summut; we's hear how it's to be. Gooid-for-naught madling! ye desarve pining fro' this to Churstmas, flinging t' precious gifts o'God under fooit i' yer flaysome rages! But I'm mista'en if ye shew yer sperrit lang" ((Brontë 85).

Joseph uses dialectal spelling as well, vowel sounds tend to be broader, e.g. in 'abaht' (about), 'heead' (head), 'neeght' (night), 'seeght' (sight) as in "Yah mun'n't drive him out of his heead for nowt!" (Brontë 68), "Bud I can look for norther horse nur man of a neeght loike this" (Brontë 69), and "how isn't that nowt comed in fro' th' field, be this time? What is he about? girt idle seeght!" (Brontë 146).

Dialectal grammar is utilized by Joseph, e.g. 'I seed' (I saw), 'comed' (came) 'wer' (was) as in "I seed young Linton boath coming and going, and I seed yah" (Brontë 71), "And how isn't that nowt comed in fro' th' field, be this time?" (Brontë 67), and "I wer sure he'd sarve ye out! He's a grand lad! He's getten t' raight sperrit in him!" (Brontë 205).

Also he uses dialectal lexis e.g. 'lugs' (ears), 'itsseln' (itself), 'Hahsomdiver' (however), 'offald' (worthless) as in ' $\mathrm{T}$ ' maister nobbut just buried, and Sabbath not o'ered, und t' sound o' t' gospel still i' yer lugs" (Brontë 17) and "He's patience itsseln wi' sich careless, offald craters-patience itsseln he is!" (Brontë 68).

In Joseph's speech, definite articles are always reduced to either $t$ ' or th '; a specific noun is preceded by t' at one point in the novel and by th' at a different point. Nevertheless, t' and th' distribution is not regular. $T$ ' appears before nouns with initial consonants only as in ' $T$ ' maister nobbut just buried, and Sabbath not o'ered, und t' sound o' t' gospel still i' yer lugs" (Brontë 266) and "we wer a'most too mucky to sow t' corn for makking her breead" (Brontë 266), whereas th' appears before nouns with initial consonants as well as nouns with initial vowels as in 'Go round by th' end o' $t$ ' laith, if ye went to spake to him" (Brontë 12) and "Maister, coom hither! Miss Cathy's riven th' back off 'Th' Helmet o' Salvation" (Brontë 18).

The use of dialect by Joseph reflects the roughness of Wuthering Heights and its environment. The old man speaks an old dialect and lives in the old farmhouse.
The house is habitable but not comfortable and subjected to stormy weather at all times. The same applies to Joseph's dialect: it is intelligible but not easily understood as in 'They's rahm for boath ye un' yer pride, now, I sud think i' the hahse. It's empty; ye may hev' it all to yerseln, un' him as allus maks a third, i' sich ill company!" (Brontë 120) which means "There's room for both you and your pride now, I should think, in the house. It's empty: you may have it all to yourself, and him who always makes a third in such bad company!"

His speech is constantly overlooked by the upper classes, yet, it is an essential part of the novel because it highlights the importance of social obstacles in the Victorian era and plays a significant role in the development of the atmosphere, the characters and their surroundings. Finally, it indicates a lack of education if a speaker uses dialect alone, as Joseph does.

Mr. Earnshaw represents a class of the wealthy though not very much educated same way as her daughter Catherine who seems to be of a wayward character. In their speech to one another, it is apparent that Mr. Earnshaw and her daughter display varying the use of the Standard English language with Mr. Earnshaw's statement containing dialect while her daughter speech does not. For instance the use of the word 'canst' and 'thou' in his scolding of her daughter: "why canst thou not always be a good lass, Cathy?" and her daughter's response "why cannot you always be a good man, father?" (Brontë 54) openly shows the influence of dialect in their speech. In another instance, after a visit to Liverpool Mr. Earnshaw uses dialect in the statement "And at the end of it, to be flighted to death" as a reference to being scared (Brontë 45).

Catherine uses trained, sophisticated, elevated, descriptive language in long sentences often complicated and punctuated by a sequence of semicolons, dashes and clauses in contradiction with the Heights colloquial dialect for example,

I cannot express it; but surely you and everybody have a notion that there is or should be an existence of yours beyond you. What was the use of my creation, if I were entirely contained here? My great miseries in this world have been Heathcliff's miseries, and I watched and felt each from the beginning: my great thought in living is himself. If all else perished, and he remained, I should still continue 
to be; and if all else remained, and he were annihilated, the universe would turn to a mighty stranger: I should not seem a part of it. My love for Linton is like the foliage in the woods: time will change it, I'm well aware, as winter changes the trees. My love for Heathcliff resembles the eternal rocks beneath: a source of little visible delight, but necessary. Nelly, I am Heathcliff! He's always, always in my mind: not as a pleasure, any more than I am always a pleasure to myself, but as my own being. (Brontë 104)

She speaks with few grammatical errors, if any, in her language, a fact that connotes that she was well raised by socially positioned individuals, as well. The linguistic variation in Mr. Earnshaw and her daughter's example through the dialect exhibition is very important in showing their social status.

One is introduced to Wuthering Heights first through the filter of Lockwood's language. The most distinguishing characteristic in Lockwood's speech is its literariness. It is stilted, pompous, mannered, somewhat bookish and riddled with clichés. He also utilizes hackneyed and impacted language, as in his description of his flirtation on the seaside with "a most fascinating crea-ture: a real goddess in my eyes" (Brontë 7). He also speaks of Cathy as "the amiable lady of Heathcliff" (Brontë 16), then of Hareton as "favoured possessor of the beneficent fairy" (Brontë 17). Taking Cathy as the wife of Hareton, he fantasizes himself to be a possible seducer of Cathy, "She has thrown herself away upon that boor from sheer ignorance that better individuals existed! A sad pity...I must beware how I make her regret her choice" (Brontë 17).

The assigning of dialects to the different characters in Wuthering Heights exhibit a vivid regional distribution of populations based on social class. One of the notable highlights of this is the incident where Lockwood questions Mrs. Dean's absence of manners that are reflective of her social class considering that Mrs. Dean herself does not speak with a dialect that is reflective of her native origins. Lockwood tells Mrs. Dean "Excepting a few provincialisms of slight consequence, you have no marks of the manners that I am habituated to consider as peculiar to your class" (Brontë 78).

In order to identify with her adopted present high social class, Mrs. Dean tells Lockwood that she has had to train herself on the mannerism of her adopted to the extent of making use of the local book library from which she has been able to master the use of the language of the high-class strata. Considering that Mrs. Dean works for the Earnshaw family as a housekeeper, it is apparent that the social lifestyle of the Earnshaw family has had a powerful impact on her (Brontë 40). Mrs. Dean finds it comfortable to identify herself with the mannerisms of the high class than those of her low class including her avoidance to speak in her native dialect.

From Lockwood's knowledge of Mrs. Dean's native origins, he is surprised to observe that she does not exhibit the dialect presented by those with a similar background. But when she talks for herself, her language is vibrant and colloquial. Using shorter, less complicated phrases than Lockwood, her story is lifelike and imaginative, using many vivid and accurate images, as in her reference to the history of Heathcliff, "It's a cuckoo's, sir, I know all about it, except where he was born, and who were his parents, and how he got his money at first. And that Hareton has been cast out like a unfledged dunnock" (Brontë 43), bursting with a sense of urgency as if she related events that transpired a couple of hours before, rather than in previous years. Therefore, one discovers that Nelly has two styles, her style is indistinguishable from modern narrative prose while speaking to Lockwood and her own story with its emphatic rhythm of speech and simple vocabulary demonstrates almost no variety.

It is also evident that Heathcliff never spoke excellent Standard English before Mr. Earnshaw found him living a socially disregarded life on the road. When he was brought to the Heights he spoke "gibberish that no one could understand" (Brontë 46). Nelly defines his voice as being foreign in tone. As a kid, he lets out a volley of curses when he is caught trespassing at the Grange, shocking his listeners and making Mrs. Linton exclaim, "Did you notice his language?"\|(Brontë 63).

He later succeeds in speaking and behaving in a polished and sophisticated way as a selfmade man, though almost illiterate. There is therefore nothing in the real spelling or grammar of the dialogue to suggest any distinction between the speech of Heathcliff and that of the other significant characters.Brontë takes him from the margins to the center of the fictitious world by minimizing differences in the language of Heathcliff. Nicholas 
Marsh authenticates that Heathcliff's speeches contain two different styles. So, in comparison with Lockwood's and Nelly's, his speech appears rough and violent. Similarly, he parodies and satirizes the speech of others particularly that of Edgar and Isabella, whose speech he treats with equal sarcasm and disdain. But as he grew under the cover of the Earnshaw family his spoken English improved immensely, and he could now communicate and articulate himself commendably using Standard English.

Hareton Earnshaw is part of the novel's second generation of families and like Joseph he has the dialect of Yorkshire in his speech as well.Unlike Joseph, Hareton was not a servant, but the property's rightful heir called Wuthering Heights. His speech is a sign of his poor education, triggered by vengeance of the Earnshaw family by Heathcliff . What embarrasses him and insults him more is that he is conscious of his inferiority but cannot do anything. Linton and Cathy take great pleasure in getting him to talk so they can laugh at him. They asked him to read but he could not so he became outrageous and growled, "Why, where the devil is the use on't?". 'Where is the use of the devil in that sentence?' tittered Linton. 'Papa told you not to say any bad words, and you can't open your mouth without one. Do try to behave like a gentleman, now do!' If thou weren't more a lass than a lad, I'd fell thee this minute, I would; pitiful lath of a crater!" (Brontë 396).

This specific element demonstrates that this novel's dialect represents more the characters' instructional level than their social or geographical situation. This can be emphasized if, for instance, one compares Joseph's speech with Nelly's, another servant whose speech, following Standard English, does not demonstrate the unique Yorkshire accent marks. Isabella also uses a familiar dialect variant to describe Hareton as a "ruffianly child, strong in limb and dirty in garb" probably in disregard (Brontë 175).

\section{Conclusion}

In conclusion, it is evident that the integration of local dialect forms an integral part of the representation of Victorian literature. In a way, use of dialect places an emphasis in either the social class or cultural identities, which the characters are associated with their background. Most of the character representation of dialect shows an indication of the regional distribution of the communities from which those characters come from. Dialect in the speeches made by the characters in Brontë's Wuthering Heights forms a significant part in revealing the character's social class. The Yorkshire dialect is associated with the servant class. In most cases, the characters that seems to perfect the use of dialect are on supporting roles to the principal characters. The use of dialect in Brontë's narrative highlights the allegiance that the characters place to their communities or their roots.

The occurrence of linguistic variations between the different characters seems to fall squarely along the premise of social class. The importance that the high class otherwise referred to as the middle-class places on their use of language forces them to have a monitoring role on their speeches to ensure that they do not display variants of the English language that is worthy of scorn. On the other hand, those who belong to the lower classes of the social hierarchy does not have trouble expressing themselves while conversing in heavily nativity-influenced dialects. In short, use of dialect in Victorian literature plays a significant role in revealing the social class of the associated characters.

\section{Works Cited}

1. Brontë, Emily. Wuthering Heights. 1847. London, Penguin Classics, 2008.

2. Chapman, Raymond. Linguistics and Literature: An Introduction to Literary Stylistics. Great Britain: Edward Arnold. 1989.

3. Ferguson, L. Susan. "Drawing Fictional Lines: Dialect and Narrative in the Victorian Novel". Style. Vol. 32, No. 1 (Spring 1998), pp. 1-17.

4. Hornberger, Nancy H. and Sandra L. McKay, editors. Sociolinguistics and Language Education. UK: St Nicholas House, 2010.

5. Linn, Michael D. Dialect and Language Variation. Revised. Elsevier, 2014.

6. Marsh, Nicholas. Emily Brontë - Wuthering Heights. London: Macmillan, 1999.

7. Mugglestone, Lynda. 'Talking Proper'. The Rise of Accent as Social Symbol. Oxford : Clarendon Press, 1995.

8. West Winds Yorkshire Tearooms. An Ancient Tongue West Winds. westwindsinyorkshire.co.uk 2010.

www.s cribd.com/document/50357470/AnAncient To ngueWestWinds. Accessed 10 May 2019.

9. Yule, George. The Study of Language. Cambridge University Press, 2010. 